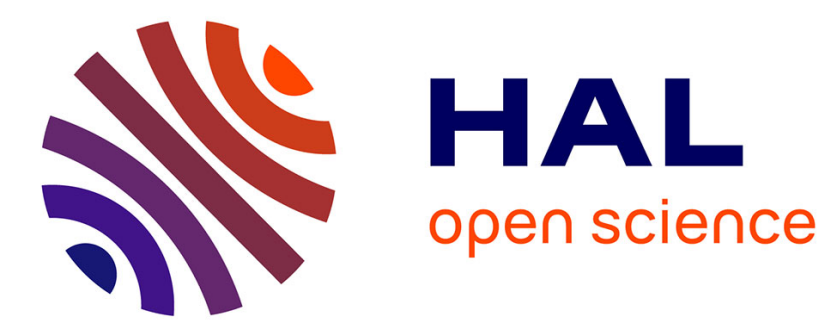

\title{
Influence of triploid status on salmon smoltification
} Gilles Boeuf, H. Seddiki, Anne-Claire Le Roux, Armelle Severe, Pierre-Yves

Le Bail

\section{To cite this version:}

Gilles Boeuf, H. Seddiki, Anne-Claire Le Roux, Armelle Severe, Pierre-Yves Le Bail. Influence of triploid status on salmon smoltification. 4. International Workshop on Salmonid Smoltification, Oct 1992, St Andrews, New Brunswick, Canada. 10.1016/0044-8486(94)90035-3 . hal-02777974

\section{HAL Id: hal-02777974 https://hal.inrae.fr/hal-02777974}

Submitted on 4 Jun 2020

HAL is a multi-disciplinary open access archive for the deposit and dissemination of scientific research documents, whether they are published or not. The documents may come from teaching and research institutions in France or abroad, or from public or private research centers.
L'archive ouverte pluridisciplinaire HAL, est destinée au dépôt et à la diffusion de documents scientifiques de niveau recherche, publiés ou non, émanant des établissements d'enseignement et de recherche français ou étrangers, des laboratoires publics ou privés. 


\title{
Influence of triploid status on salmon smoltification
}

\author{
Gilles Boeuf $^{\mathrm{a}, *}$, Hachim Seddiki ${ }^{\mathrm{a}}$, Annick Le Roux ${ }^{\mathrm{a}}$, Armelle Severe ${ }^{\mathrm{a}}$, \\ Pierre-Yves Le Bail ${ }^{b}$ \\ ${ }^{a}$ IFREMER, BP 70, 29280 Plouzane, France \\ 'INRA, Campus de Beaulieu, 35042 Rennes, France
}

\begin{abstract}
Growth and survival in fresh water ( $F W$ ), completion of smoltification, and subsequent growth in seawater (SW) of diploid $(2 n)$ and triploid ( $3 n$ ) Atlantic salmon were compared. $3 \mathrm{n}$ eggs were produced by thermal shock $\left(10 \mathrm{~min}\right.$ at $\left.29^{\circ} \mathrm{C}\right)$ and verified by caryological examination of young embryos ( $86 \%$ survival) and, later on 9 -month-old juveniles, by measurement of erythrocyte nuclear diameter $96 \% 3 \mathrm{n}$ ). Parr were reared in four tanks (Le Conquet hatchery) under natural temperature and photoperiod $\left(48^{\circ} \mathrm{N}\right)$. Survival from first-feeding ( 20 March) to smolting (mid-April of the next year) was $84.3 \%$ in the $2 \mathrm{n}$ and $81.4 \%$ in the $3 \mathrm{n}$ fish. At completion of smolting, the triploid salmon were significantly larger than diploid fish $(171 \pm 2$ vs $163 \pm 2 \mathrm{~mm} ; P<0.01)$ but both groups exhibited the same condition factor (1.04 \pm 0.03 ). Gill microsomal $\mathrm{Na}^{+}, \mathrm{K}^{+}-$ATPase activity showed similar patterns in both groups, increasing from mid-February, both peaking on 21 ApriI at $30.1 \pm 2.2 \mu \mathrm{mol} \mathrm{PO}_{4} \cdot \mathrm{mg}$ prot $^{-1} \cdot \mathrm{h}^{-1}$. In contrast, $2 \mathrm{n}$ and $3 \mathrm{n}$ fish exhibited significant differences in plasma thyroid hormones $\left(T_{3}\right.$ and $\left.T_{4}\right)$ and growth hormone $(G H)$ levels. $\mathrm{T}_{3}$ increased in $2 \mathrm{n}$ fish at the end of March, reaching $12.5 \pm 1 \mathrm{ng} \cdot \mathrm{ml}^{-1}$, but in $3 \mathrm{n}$ fish remained low and varied little after the beginning of March $\left(1.5 \mathrm{ng} \cdot \mathrm{ml}^{-1}\right) . \mathrm{T}_{4}$ surged in 2n saimon on 28 March $\left(19.5 \pm 1.5 \mathrm{ng} \cdot \mathrm{mI}^{-1}\right)$, but peaked later in $2 \mathrm{n}$ fish (15 April) and at a lower level $\left(10.2 \pm 1.2 \mathrm{ng} \cdot \mathrm{ml}^{-1}, P<0.01\right)$. GH levels increased in $2 \mathrm{n}$ fish in late March, reaching $12.2 \pm 1 \mathrm{ng} \cdot \mathrm{ml}^{-1}$ on 4 April, significantly $(P<0.01)$ bigher than the 3 n salmon $\left(8.0 \pm 0.5 \mathrm{ng} \cdot \mathrm{ml}^{-1}\right)$.

Both $2 \mathrm{n}$ and $3 \mathrm{n}$ groups were transferred directly to $35 \%$ SW on 18 April. Both groups showed good hypo-osmoregulatory ability. Plasma osmolality and chloride after $48 \mathrm{~h}$ in $\mathrm{SW}$ were $362 \pm 2 \mathrm{mOsm} \cdot \mathrm{l}^{-1}$ and $148 \pm 2 \mathrm{mM} \cdot \mathrm{I}^{-1}$ in $2 \mathrm{n}$ and $360 \pm 2$ and $149 \pm 4$ in $3 \mathrm{n}$ smolts. Mortality after 21 days in SW was $3 \%(2 n)$ and $4 \%(3 n)$.

Long-term results in net pens showed better performance in $2 \mathrm{n}$ than in $3 \mathrm{n}$ salmon in SW. In June, after 14 months in SW, survival of $2 \mathrm{n}$ salmon was $70 \%$ and only $45 \%$ for $3 \mathrm{n}$ fish. At this time, $2 \mathrm{n}$ and $3 \mathrm{n}$ salmon weighed 1.568 and $1.420 \mathrm{~kg}$, respectively. Although triploid Atlantic salmon are used in Scotland, Canada and Tasmania, the seawater rearing of $3 \mathrm{n}$ salmon in France may not be practicable because of local environmental conditions. Triploids appeared able to adapt to $S W$ but their growth and survival were inferior to those of $2 n$ fish. The endocrinological differences between $2 n$ and $3 n$ fish may be responsible for relatively poor performance of $3 n$ salmon in $\mathrm{SW}$.
\end{abstract}

*Corresponding author. 


\section{Special Issue}

\section{Salmonid Smoltification IV}

Proceedings of a Workshop hosted by the Department of Fisheries and Oceans, Biological Station, St. Andrews, New Brunswick, Canada

Held at the Harry B. Hachey Conference Centre, St. Andrews Biological Station, 19-23 October 1992

\section{Guest Editors:}

RICHARD L. SAUNDERS

Department of Fisheries and Oceans, Biological Station, St. Andrews, N.B. E0G 2X0, Canada

TILLMANN J. BENFEY

Department of Biology, University of New Brunswick, Fredericton, N.B. E3B 6E1, Canada

TERRANCE M. BRADLEY

Department of Fisheries, Animal and Veterinary Sciences, University of Rhode Island, Kingston, RI 02881, USA

JAMES DUSTON

Connors Bros. Limited, Aquaculture Division, Blacks Harbour, N.B. E0G 1H0, Canada

\section{GIL J. FARMER}

Department of Fisheries and Oceans, Fish Culture Section, P.O. Box 550, Halifax, N.S. B3J 2S7, Canada

STEPHEN D. McCORMICK

Northeast Anadromous Fish Research Laboratory, U.S. Fish and Wildlife Service, P.O. Box 796, Turners Falls, MA 01376, USA

JENNIFER L. SPECKER

Department of Zoology, University of Rhode Island, Kingston, RI 02881, USA

\section{Section Editor, Physiology and Endocrinology:}

NIALL BROMAGE

Institute of Aquaculture, University of Stirling, Stirling FK9 4LA, UK 